\title{
The effect of training, mentality and entrepreneurship on business success for employee pensions
}

\author{
Ferry Sinaga \\ Postgraduate Doctoral Program in Jakarta State University
}

Suryadi
Lecturer in Jakarta State University

Ma'ruf Akbar

\begin{abstract}
This study aims to analyze (1) the direct effect of training on business success for prospective retirees; (2) the direct effect of mentality on business success for prospective retirees; (3) the direct effect of entrepreneurship on business success for prospective retirees; (4) the direct effect of training on entrepreneurship for retirement candidates PT. Bank BNI; (5) the direct effect of mentality on entrepreneurship for prospective retirees; and (6) the direct effect of training on the mentality of prospective retirees. The population in this study was retired PT. BNI banks in the Indonesian region that attended pre-retirement training at the time of retirement (aged 50-55 years) was 264 people. The sampling technique using Slovin formula obtained as many as 160 respondents. The results of the study indicate that (1) the training implemented has been actualized to retired PT. Bank BNI employees to realize the success of the business that will be undertaken. The training was in the form of pre-retirement given to every retired PT. Bank BNI as a provision for entrepreneurship in retirement; (2) retired employees are mentally prepared to pursue business in realizing business success. This mentality is needed as the stability of the soul and personality to run the business to be successful; (3) retired employees carry out entrepreneurship to realize business success. Entrepreneurial desire is the main motive for realizing the success of the business he is engaged in; (4) provide continuous training to retired employees to prepare them for entrepreneurship. The results of the pre-retirement training that were followed provided benefits for running entrepreneurship; (5) every retired employee is ready to carry out the entrepreneurial mentality he is practicing. Mental readiness to dare to make entrepreneurial decisions in retirement; and (6) retired employees who attend training mentally are ready to face the retirement period with entrepreneurship. Training before retirement has led to the realization of a persistent mentality in entrepreneurship.
\end{abstract}

Keywords: Training, Mentality, Entrepreneurship, Business Success.

\section{INTRODUCTION}

The working world of an employee, in addition to the initial period of being an employee, is a retirement period that must be dealt with and well prepared. During this retirement, it is undeniable that the level of income obtained by employees is no longer the same as what was obtained by the employee at the time he was still actively working. A retired employee must experience a decrease in income from being received each month while still actively working at a retirement salary which is an average of $30 \%$ of salary receipts while still active employees. The level of decline in income of $70 \%$ (seventy percent) of the usual received does not automatically correspond to the decrease in the level of expenditure of the same magnitude. Generally, expenses for living expenses in retirement are approximately $60 \%$ when compared to spending during active periods. Means that the pension received during retirement is not sufficient, especially providing financial freedom compared to the pension income received. 
On the other hand, along with the increasing awareness of the Indonesian people about the level of living health, then at retirement age, which on average 55 years and above most of the employees who will enter retirement have a level of productivity that is still quite good in carrying out activities which results in his life, especially to guarantee financial freedom in his old age. There are several alternative solutions that can be chosen as an effort to guarantee financial freedom, including pursuing entrepreneurship, opening a business that can provide additional income or conduct various productive activities such as becoming a banking consultant or educator / instructor in the banking sector. But in reality, not all employees are able to have initiative and innovation to prepare them for retirement. Therefore, it is a consideration for every employee who faces retirement to be able to develop his potential to plunge into building his own business, becoming entrepreneur or an entrepreneur. Everyone has the ability and potential to become an entrepreneur, and this is a great opportunity for an employee who can use and use the opportunities he has by managing or utilizing the money provided by the company as his property to be used for entrepreneurial activities, so that after retiring employees are able to remain productive in entrepreneurship.

Facing employee retirement opportunities has been given by PT. Bank BNI (Bank Negara Indonesia) when obtaining supporting funds when ending the active period taken from the salary in question which has been deducted every month to be deposited and given to employees. The range of these funds ranges from hundreds of millions to even billions, according to the career position that he occupies and the length of work the is doing. The provision of these funds is certainly a capital that must be considered and utilized by employees optimally by using and utilizing it to build entrepreneurship. The description of employees who have attended pre-retirement training who have plunged to use the funds to conduct entrepreneurial activities through their families is approximately $15 \%$, while other employees prefer to do entrepreneurial activities after retirement as much as $60 \%$, and the remaining $25 \%$ of employees do infestations. Among the $15 \%$ who have tried, there is a small number who have succeeded in developing entrepreneurship, while others are still looking for opportunities and forms of prospective entrepreneurial business, and there are also those who experience a decrease in turnover even out of entrepreneurial activities they do.

Evidence that shows that employees who have not succeeded in developing their business can be seen from the success of businesses that have not been optimized to utilize the ability of venture capital in increasing turnover and managing business capital, have not yet obtained profitable business income and increased earnings income, volume and sales distribution. Less Including the production output of the business produced has not increased and absorbed the number of workers as employees, according to the needs and competencies of working people. The reasons underlying the achievement of success are only $10 \%$ to $15 \%$, because employees who pursue the field of entrepreneurship do not have the entrepreneurial concept to create their own jobs which provide great benefits and benefits to many parties. The manifestation of the lack of entrepreneurial concepts possessed by employees is because they are less able to actualize the concept of entrepreneurship, which is lack of confidence in entrepreneurship, less task oriented and results, not yet willing to take risks, do not have adequate leadership, less innovative and not future oriented. Seeing the gap from previous retirees when utilizing a given pension fund that chose to entrepreneurship, there were three unsuccessful, ordinary and partially successful tendencies, then facing retirement needs to take training and mental preparation to have readiness to pursue the field of entrepreneurship in order to realize success in entrepreneurship. Training needs to be followed by every employee who wants to face retirement, this is important to provide reinforcement for employees in having the competence to pursue the field of entrepreneurship that is able to realize business success. The thing that needs to be addressed about this training is that it relates to aspects of knowledge, 
skills and attitudes in a comprehensive entrepreneurship in accordance with the insights on the type of business that wants to be engaged in.

The importance of training is an interesting thing to be considered by every employee in facing retirement to enter the field of entrepreneurship that is oriented to business success. Therefore, it is necessary to strengthen the employee mentality in addressing readiness to accept and utilize retirement as an opportunity to achieve business success. Changes in the status of employees who are still acting as retired employees without any productive activities that support them will affect the mental changes quite dramatically. It needs to be cultivated in every employee facing retirement to have self-awareness, self-hope and self-assessment in the retirement that he faces. The fact shows that there are still many employees who have a nonconditional mentality after retirement, do not have an orientation to face retirement. Still found employees do not have enough self-awareness that retirement is certainly different from the time when actively working. During automatic retirement, there is no work activity if it is not created, therefore there needs to be self-awareness to be able to create and create a separate activity or business, one of which is entrepreneurship.

On the other hand, employees who face retirement are still not ready for retirement. There are those who are lacking in enthusiasm, not aggressive and progressive to face their retirement, so motivation is needed to always be enthusiastic in their work and to take advantage of the opportunities they have for entrepreneurship during the pension period. As there are still many employees facing retirement, they have not developed a self-assessment in behaving positively and are optimistic about the conditions of retirement that must be lived. Employees in the face of retirement must be able to be big-spirited in assessing themselves that at retirement the opportunity to pursue their own business becomes important to entrepreneurship to realize the success of starting their own business. This description is an implication of the development of the science of education management as a learning process for employees of prospective retirees to participate in training activities, preparing mentally as a process of character, learning, strengthening entrepreneurship for business education and business success as a very important learning process in education management

\section{Basic Theoretical Management of Education}

\section{LITERATURE REVIEW}

The effect of training, mentality and entrepreneurship on the business success of retired employees of Bank Negara Indonesia (BNI) is part of education management. Educational management theories that can be used according to the relevance of this research include classical theory, neo classical theory and modern theory. The classical theory pioneered by Frederick W. Taylor. The actualization of the application of the classical theory of education management has found weaknesses, where these weaknesses are essentially not everyone able to develop their potential without the involvement of others to provide motivation in carrying out their activities, so the neo-classical theory in education management was pioneered by Vroom. Modern theory as part of education management views every human being in a situational perspective in developing his own potential. The three education management theories above have relevance to educational theory commonly used in the teaching and learning process. One application of the well-known learning theory is John Dewey's theory of learning by doing theory which is a theory of the sub-ordinate educational theory.

\section{Business Success}

The concept of business success is a concept in the view of education management, very necessary and has strong substance for everyone to able to realize success in him to carry out 
various productive businesses. Understanding success means things or circumstances a person can stand alone without relying on other people after success in trying. Success is basically a condition where a person does not depend on authority and does not need full direction, but is able to find solutions and provide the best solutions for the business he is engaged in (Sutrisno, 2013). The meaning of success is a goal for everyone in trying or trying to wrestle a job that directs to not depend, but can provide solutions or problem solving after going through a process of experience in business, so that success in the field they are engaged in. There are several components of business success that must be addressed in doing a business.

Component of success that must be possessed by every person who prepares himself for success in business is the component of progressive, resilient, initiative, having control from within (internal focus and control) and self-stability (mental confidence). This component of success becomes important and necessary for everyone in doing or starting a business (Thomas and Norman, 2008). The definition of business success in the view of Rhondra Abrams (2010) states that the successful is feeling of satisfaction and completion when you are a career is more successful than monetary rewards.. The above definition shows that the success of a business is a disclosure of feelings of satisfaction and a solution that is obtained when a career has ended, successfully having another dimension that is more real or more than just a financial value award. Business success was also put forward by Julian (2014) who stated that the success of business is a process that has planned and directed implementation of business career goals, which success includes emotional and spiritual mentality which support of person able to development of business which success. Business success is a planned and directed process of awareness in realizing a business career goal, success which includes mentality, emotional and spiritual which encourages a person to be able to develop a business in realizing its success. The importance of success has a very fundamental meaning, so success becomes important and becomes an essential element that must be realized by every person who has an entrepreneurial spirit by always participating in various trainings and developing mentality.

\section{Entrepreneurship}

The application of the concept of entrepreneurship in the education management perspective is a concept related to the implementation of management that directs one or more people to carry out their work according to the objectives to be achieved. Entrepreneurship is a status or profession of people who are involved in business. Therefore the concept of entrepreneurship needs to be understood and understood in various perspectives. Included in the perspective of education management studies focuses on the concept of entrepreneurship.

Following is the understanding of etymology entrepreneurship. The definition of entrepreneurship stated above, in principle is an interpretation of the attitudes and behaviors possessed by a person or group to have independent attitudes and behaviors in trying to combine elements of creativity, taste and work into creativity. to produce various opportunities and make a profit. The important meaning of entrepreneurship is to make efforts in various businesses to be able to develop the potential of a person trying to suit various innovations, creations, appreciation and motives to develop a business that is advanced and profitable.

Entrepreneurship as a spirit, attitude, behavior and ability of a person to handle a business or activity that leads to efforts to find, create and implement new ways of working, technology and products by increasing efficiency in order to provide better services and or gain greater profits (RL Craig, 2008). Entrepreneurship has different meanings among experts or reference sources because of the variety of emphasis and emphasis. Define entrepreneurship asmental 
employmentor create their own jobs which provide great benefits and benefits to many parties. An entrepreneur makes a business now and develops in the future by making a profit. So this definition places more emphasis on how someone makes a business or develops his business.

\section{Training}

Describing the training concept observed in this study is the training that is followed by PT. Bank BNI pensioners, because it requires an understanding of the meaning, purpose and benefits of training. There are various opinions about this matter, but in principle the training is interpreted as a systematic and organized procedure to be able to increase knowledge, skills and attitudes that are practical for certain purposes. Training is the process of short time education which method and procedure systematically and organize. The trainer will learn from practice and implementation of goals. Training as a process which aims to obtain knowledge and training for suitable with work need it (Dugan, 2014).

Training is defined as a short-term educational process that uses systematic and organized methods and procedures. Trainees will learn practical knowledge and skills to realize their goals. The approach applied in the training proposed by James (2011), a processto training and development, provides a comprehensive and practical introduction to the fields of organizational training and human resource development. It surveys the methods, functions and goals of training from need assessment to implementation in organizations. Training is a process that helps others to acquire knowledge and skills that are appropriate to the needs of the work they are engaged in. This gives an indication that training is needed and expected as something that is meaningful for everyone to be able to develop the skills and skills of knowledge to complete the work they are carrying out. The meaning of training is to provide a process to master the work based on the knowledge, skills and attitudes that are owned, in order to be able to develop all of its potential. The meaning of training is basically the process of providing assistance to workers to master special skills or help to correct deficiencies in carrying out their work. Training can also be interpreted as an action to improve a person's knowledge, skills and attitudes in carrying out certain work. Through training that is followed, one is able to obtain, improve and develop its performance, discipline, attitude and work ethic at a certain skill level based on knowledge prerequisites to develop a skill according to the attitude that can be used as the ability to work optimally in realizing its goals.

\section{Mentality}

Mentality is inseparable from mental understanding itself which is definitively no clear definition. Etymologically the word mental comes from Greek which has the same meaning as psyche, meaning psychic, mental or mental. RL Craig (2008) states mentality as "revering to the mind", meaning something related to the mind and mind itself. Simply mentally understood as something related to the heart and character or character, not physical. Mental words are taken from Latin, namely from the word mens or metis which means soul, life, soul, spirit and spirit. Mental are things related to psicho or psychology that can affect individual behavior. Every behavior and expression of individual movements is an encouragement and reflection of the condition or mental atmosphere.

Mental is a comprehensive blend of various psychological functions with the ability to deal with psychological crises that afflict humans that can affect emotions and from these emotions will affect mental states. Mental is defined as relating to thoughts, intellect, memories or processes associated with thoughts, reason and memories. Such as forgetting, lazy to think, unable to concentrate, shortsighted, greedy, pretentious, unable to make a good and right decision, not even able to distinguish right from wrong, lawful or unclean. Mental is related to 
reason (mind / ratio), soul, heart (heart) and ethics (moral) and behavior. One unit that forms a good and bad mentality or personality (self image) that depends on the mentality it makes. Zakiyah (2009) states that individual conditions can be seen from joy, sadness and even loss of passion for life, all depending on their mental and psychological capacity. Individuals who do not have a strong mental defense system in dealing with all life problems or do not have a strong self-defense system to control their souls, individuals will experience a variety of psychiatric disorders that affect personality conditions that lead to pathological behavior.

The mental conditions are classified into two forms: healthy mental conditions and unhealthy mental conditions. A healthy mental condition will give birth to a normal person. Person who normally is to shape the behavior of individuals who do not deviate from the behavior in general, where an individual was living, and personal that normally would demonstrate behavior that is harmonious and appropriate (adequate) and be accepted by society in general, where the attitude of his life in accordance with the norms and lifestyle of the environment. Simply put, individuals are able to adapt naturally (Zakiyah, 2009). So this normal and mentally healthy person can be felt in self-condition or feeling conditions that tend to be stable, not much harboring internal conflicts, calm moods and physical conditions that always feel healthy. While those who need to be watched and watched out by individuals are unhealthy mental conditions, because unhealthy mental conditions will form an unhealthy personality (abnormal). Based on the formulation of the problem and the description above, the hypothesis of this study as follows: 1) training directly affects the success of the business for retired employees of PT. Bank BNI; 2) mentality directly influences the success of the business for retired employees; 3) entrepreneurship has a direct effect on the success of business for retired employees; 4) training directly affects the entrepreneurship of retired employees; 5) mentality directly influences the entrepreneurship of retired employees of Bank Negara Indonesia; and 6) training directly affects the retirement mentality of employees.

\section{RESEARCH METHODS}

This research was conducted at PT. Bank BNI with research time starting from January to August 2018. This study uses a quantitative approach with survey methods. The unit of analysis is a retired PT. Bank BNI employee. The population in this study were retired employees of PT. Bank BNI in the Indonesian region who attended pre-retirement training at the time of retirement (aged 50-55 years) as many as 267 people. The sampling technique using Slovin formula obtained as many as 160 respondents. The techniques used in this study include observation, questionnaires, interviews and documentation. The data analysis used for this study is descriptive analysis and inferential analysis. Descriptive analysis was used in terms of data presentation, central size and size of spread. Inferential analysis is used to test hypotheses using path analysis (path analysis) which is preceded by normality, reliability and regression analysis.

\section{RESULTS AND DISCUSSION}

The description of data in this section includes business success instrument data (Y) called endogenous variables, training (X1) and mentality instruments (X2) as exogenous variables and entrepreneurial instruments (X3) as intervening variable. The following description of the recapitulation of the variables: 
Table 1. Variable descriptions

\begin{tabular}{lccccccc}
\hline \multicolumn{1}{c}{ Variable } & xmin & xmax & Range & Mean & St. Dev. & Median & Mode \\
\hline Business success & 56 & 139 & 10 & 3.95 & 8.063 & 98 & 99 \\
Training & 61 & 100 & 5 & 4.17 & 6.260 & 81 & 98 \\
Mentality & 52 & 75 & 3 & 2.97 & 4.260 & 60 & 64 \\
Entrepreneurship & 88 & 150 & 7 & 4.28 & 8,067 & 119 & 119 \\
\hline
\end{tabular}

Before the analysis is carried out path (path analysis), data must meet several requirements of statistical tests, namely error normality test and significance and linearity test of the regression coefficient. Based on the results of the calculation of regression estimation error normality that is $\hat{Y}=\mathrm{a}+\mathrm{bX}_{1}$ obtained a constant value and slope $\mathrm{b}$ value with equation $\hat{Y}=$ $103,4302593-3,08084 \mathrm{X}_{1}$, and obtained L-statistic $=0,140$, while L-table with respondents 160 (n $=160$ ) on $\alpha=0.05$ of 3,461. In accordance with the test criteria, indicating that the results of the calculation of $\mathrm{L}_{\text {-statistic }}=0.140<\mathrm{L}$-table $=3.461$. This shows the distribution of error estimates of the business success regression equation $(\mathrm{Y})$ for training $\left(\mathrm{X}_{1}\right)$ retired PT. Bank BNI employees coming from populations that are normally distributed.

Furthermore, the results of the calculation of regression estimation error normality are $\hat{Y}=\mathrm{a}+$ bX2 obtained by a constant value and slope b value with equation $\hat{Y}=103,4302233-4,05866$ $\mathrm{X}_{2}$, and obtained L-statistic $=0,151$, while L-table with respondents $160(\mathrm{n}=160)$ on $\alpha=0.05$ of 3,461 . In accordance with the test criteria, shows that the results of the calculation of $\mathrm{L}_{\text {-statistic }}=$ $0.151<\mathrm{L}$-table $=3.461$. This shows the distribution of estimated regression success estimates of business success $(\mathrm{Y})$ for mentality $\left(\mathrm{X}_{2}\right)$ retired PT. Bank BNI employees from populations that are normally distributed. The results of the calculation of regression estimation error normality are $\hat{Y}=\mathrm{a}+\mathrm{bX}_{3}$ obtained by a constant value and slope $\mathrm{b}$ value with equation $\hat{Y}=$ $103,430339-2,13462 \mathrm{X}_{1}$, and obtained $\mathrm{L}_{\text {-statistic }}=0,144$, while L-table with respondents $160(\mathrm{n}=$ 160 ) on $\alpha 0.05$ of 3,461 . In accordance with the test criteria, indicating that the results of the calculation of L-statistic $=0.141<\mathrm{L}$-table $=3.461$. This shows the distribution of regression estimates of business success errors $(\mathrm{Y})$ for entrepreneurship $\left(\mathrm{X}_{3}\right)$ retired PT. Bank BNI employees from populations that are normally distributed. The last test required before the analysis is the test of significance and linearity of the regression model. Linearity test intends to test whether the independent variable regression line on the dependent variable has a linear relationship or vice versa. If the two data are linearly related, then the predictions of the two variables have a direct relationship. The test results show that all regression equation models are significant. After the data is obtained, processed and reviewed through the various tests required, the next step in testing the causality model is to conduct of path analysis. Based on a theoretically formed causal model, path analysis diagrams will be obtained and the coefficient value counts for each path. 
The model of Relationship between Variables in Substructure 1

$$
Y=0.100 X_{1}+0.251 X_{2}+0.198 X_{3}
$$

Path Diagram Structure 1 is presented in the following figure:

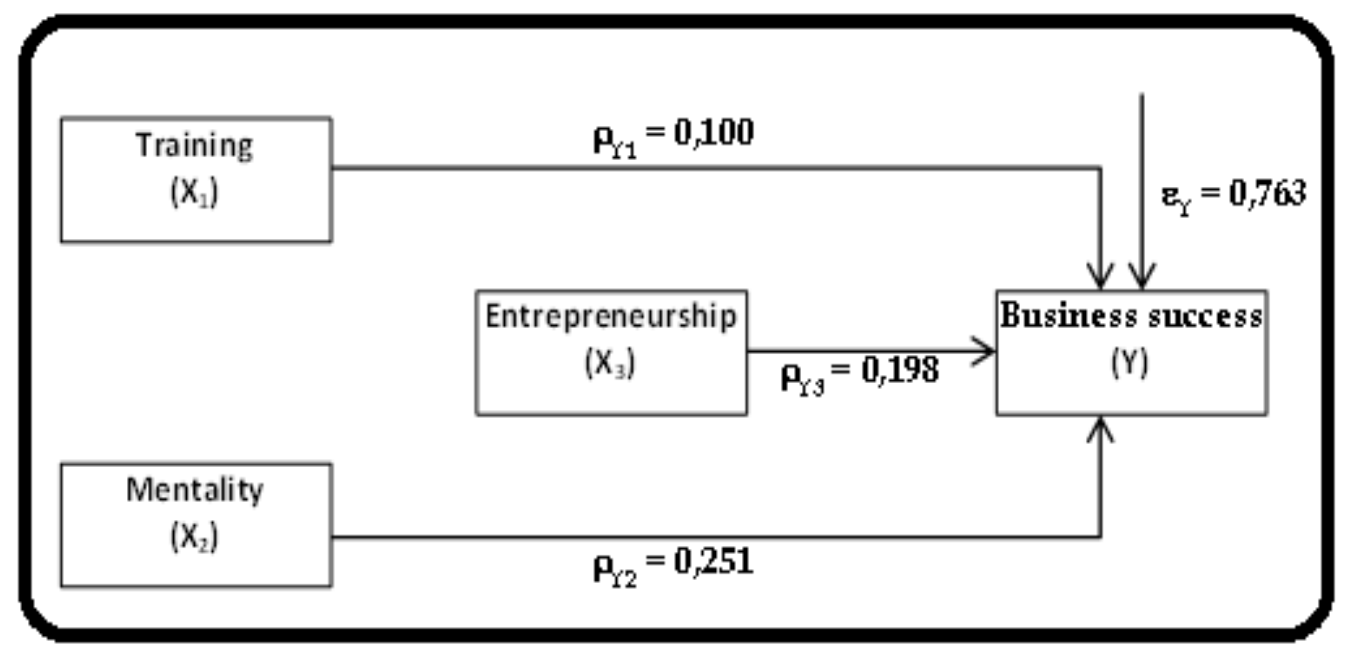

Figure 1. A Causal Relationship Model (Substructure 1)

The model of Relationship between Inter-Variables in Substructure 2

$$
\mathrm{X}_{3}=0.441 \mathrm{X} 1+0.387 \mathrm{X} 2
$$

Path Diagram Structure 2 is presented in the following figure:

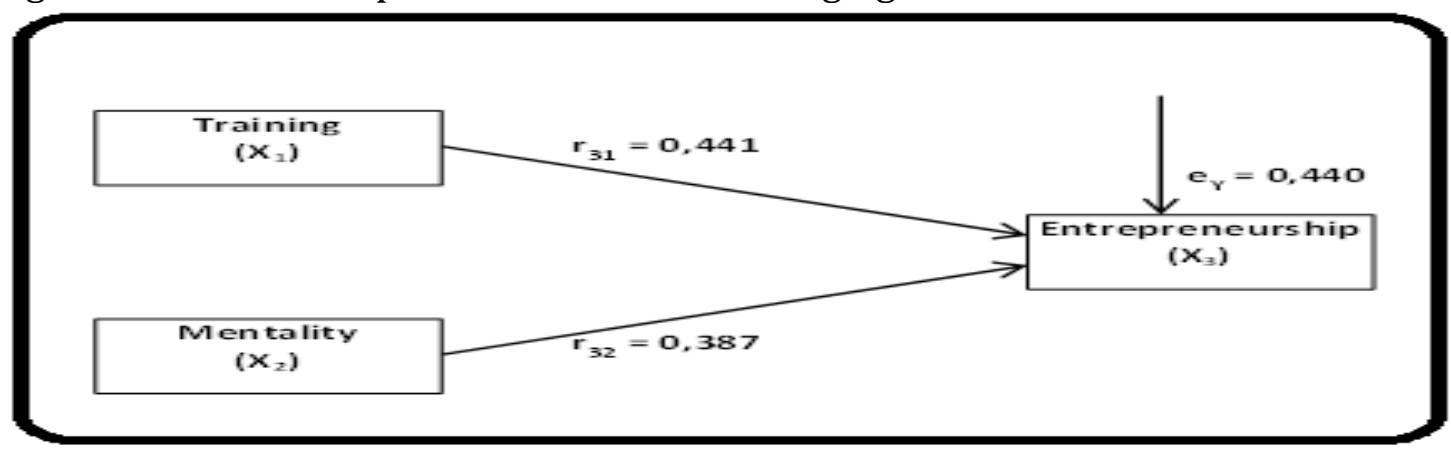

Figure 2. A Causal Relationship Model (Substructure 2)

The model of Relationship between Variables in Substructure 3

$$
\mathrm{X}_{2}=0.633 \mathrm{X} 1
$$

Path Chart Structure 3 is presented in the following figure:

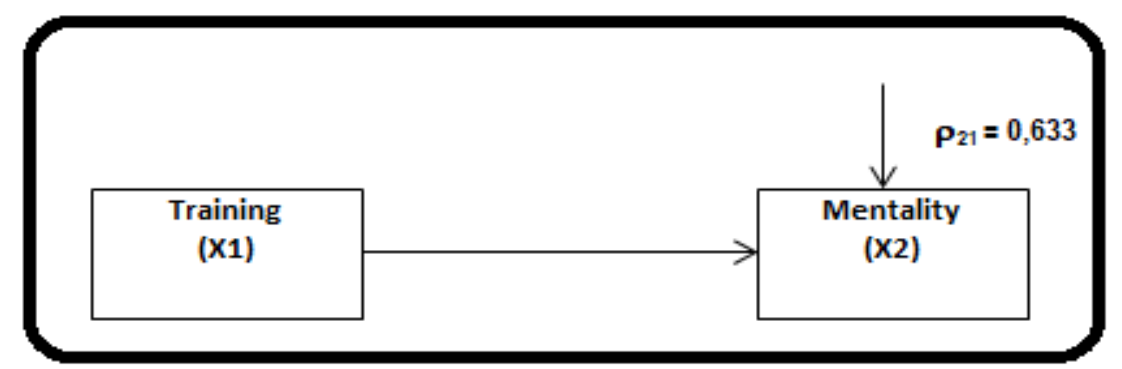

Figure 3. A Causal Relationship Model (Substructure 3) 
In accordance with what is written in Figure 1, 2, 3 shows that of the 6 (six) coefficients studied, it turns out that all path coefficients were identified significantly at $\alpha=0.05$. The empirical path diagram of the research can be seen in Figure 4:

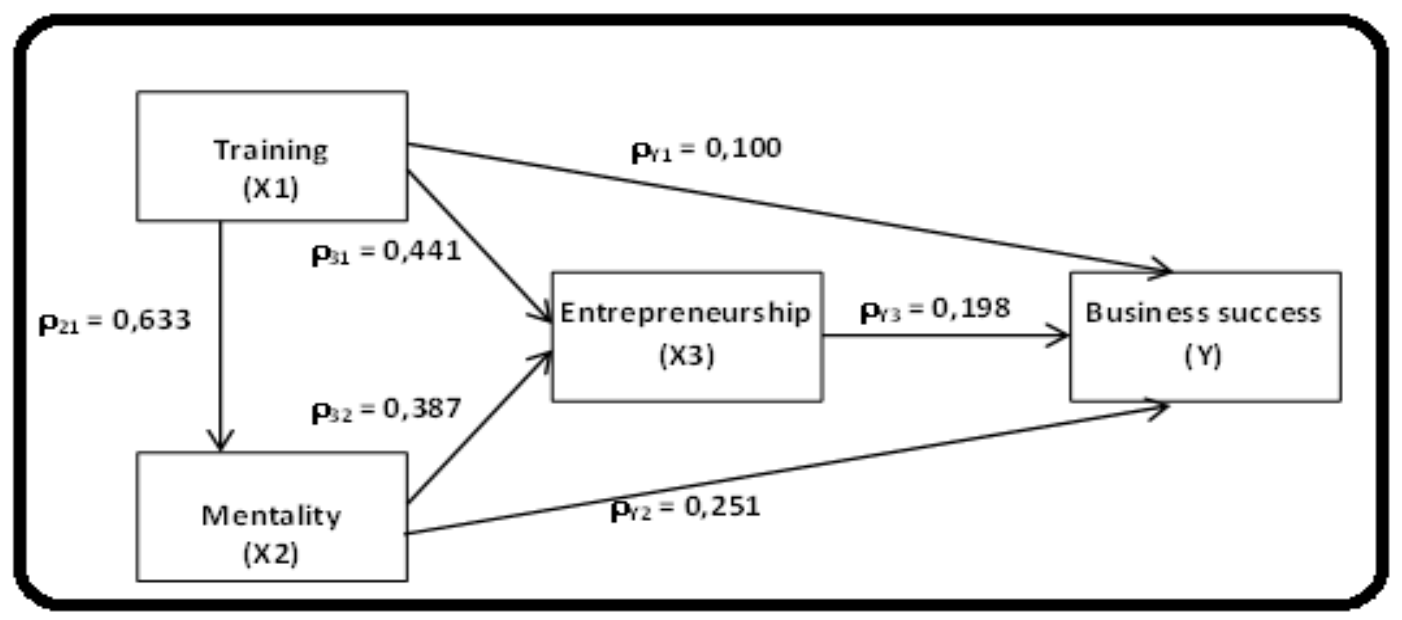

Figure 4. A causal relationship overall model

After the analysis of the structural model has been carried out, the calculation results obtained are used to test the hypothesis to know the direct and indirect effects between variables. The conclusion is by calculating the path coefficient value and significance for each path studied. The results of the decisions of all hypotheses proposed, can be described as follows:

Table 2. Hypothesis Testing

\begin{tabular}{|c|c|c|c|c|}
\hline Effects & $\begin{array}{c}\text { Path } \\
\text { Coefficient }\end{array}$ & t-statistic & $\begin{array}{c}\text { t-table } \\
(\alpha=0,05)\end{array}$ & Test Specification \\
\hline $\mathrm{X} 1 \rightarrow \mathrm{Y}$ & $\rho_{\mathrm{y} 1}=0,100$ & 0.984 & 1,65 & $\begin{array}{l}\mathrm{H}_{0} \text { accepted, } \mathrm{H}_{1} \text { rejected = Training }\left(\mathrm{X}_{1}\right) \text { has a positive } \\
\text { and significant effect directly on business success }(\mathrm{Y})\end{array}$ \\
\hline $\mathrm{X} 2 \rightarrow \mathrm{Y}$ & $\rho_{\mathrm{y} 2}=0,251$ & 2.532 & 1,65 & $\begin{array}{l}\mathrm{H}_{0} \text { rejected, } \mathrm{H}_{1} \text { accepted = Mentality }\left(\mathrm{X}_{2}\right) \text { has a positive } \\
\text { and significant effect directly on business success }(Y)\end{array}$ \\
\hline $\mathrm{X} 3 \rightarrow \mathrm{Y}$ & $\rho_{\mathrm{y} 3}=0,198$ & 1,881 & 1,65 & $\begin{array}{l}\mathrm{H}_{0} \text { rejected, } \mathrm{H}_{1} \text { accepted = Entrepreneurial }\left(\mathrm{X}_{3}\right) \text { has a } \\
\text { positive and significant effect directly on business } \\
\text { success }(\mathrm{Y})\end{array}$ \\
\hline $\mathrm{X} 1 \rightarrow \mathrm{X} 3$ & $\rho_{31}=0,441$ & 6,453 & 1,65 & $\begin{array}{l}\mathrm{H}_{0} \text { rejected, } \mathrm{H}_{1} \text { accepted }=\text { Training }\left(\mathrm{X}_{1}\right) \text { has a positive } \\
\text { and significant effect directly on entrepreneurship }\left(\mathrm{X}_{3}\right)\end{array}$ \\
\hline $\mathrm{X} 2 \rightarrow \mathrm{X} 3$ & $\rho_{32}=0,387$ & 5,654 & 1,65 & $\begin{array}{l}\mathrm{H}_{0} \text { rejected, } \mathrm{H}_{1} \text { accepted }=\text { Mentality }\left(\mathrm{X}_{2}\right) \text { has a positive } \\
\text { and significant effect directly on entrepreneurship }\left(X_{3}\right)\end{array}$ \\
\hline $\mathrm{X} 1 \rightarrow \mathrm{X} 2$ & $\rho_{21}=0,633$ & 10,274 & 1,65 & $\begin{array}{l}\mathrm{H}_{0} \text { rejected, } \mathrm{H}_{1} \text { accepted }=\text { Training }\left(\mathrm{X}_{1}\right) \text { has a positive } \\
\text { and significant effect directly on mentality }\left(\mathrm{X}_{2}\right)\end{array}$ \\
\hline
\end{tabular}

\section{CONCLUSION AND DISCUSSIONS}

Based on the results of the analysis of the training, mentality and entrepreneurship variables on business success, it can be concluded as follows: 1) the training implemented has been actualized to retired PT. Bank BNI employees to realize the success of the business that will be undertaken. The training is in the form of pre-retirement given to every PT. Bank BNI pensioner as a provision for entrepreneurship in retirement; 2) retired employees are mentally prepared to pursue business in realizing business success. This mentality is needed as the stability of the soul and personality to run the business to be successful; 3) retired employees run entrepreneurship to realize business success. Entrepreneurial desire is the main motive for realizing the success of the business he is engaged in; 4) provide continuous training to retired employees as a provision to run entrepreneurship. The results of the preretirement training that were followed provided benefits for running entrepreneurship; 5) 
every retired employee is ready to carry out the entrepreneurial mentality he is practicing. Mental readiness to dare to make entrepreneurial decisions in retirement; 6) retired employees who attend training mentally are ready to face the retirement period with entrepreneurship. Pre-retirement training has led to the realization of a persistent entrepreneurial mentality in entrepreneurship.

\section{References}

Dugan, Laird. (2014). Approaches to Training and Development. Third Edition. Revised and Upd Edition ISBN-13: 978-0738206981.

James, Draver. (2011). A Dictionary of Psychology. New York: Pengin Books, t.th. pp. 169.

Julian, Pencila. (2014). Success is about Evolving Mentality, Emotionally and Spiritually and Engaging Yourself Within A Broader Spectrum. Pinterest, New York. Pg. 223.

Kartini, Kartono \& Jenny Andari, (2009). Mental Hygiene and Mental Health in Islam. Bandung: Mandar Maju. Pg. 3.

Nasution. S. (2012). Fundamentals of Organizations. Yogyakarta: Gajah Mada University Press. p. 83.

Rhonda, Abrams. (2010). Successful Business Plan: Secrets and Strategies. Published by Planning Shop, New York. ISBN 1933895144. Pg. 155.

RL, Craig. (2008). Training and Development Handbook, a Guide to Human Resource Development. American Society for Training and Development (ASTD), McGraw Hill Book Company. Pg.. 223.

Sutrisno (2013). Management Entrepreneurship and Business Success. Jakarta: PT. Gramedia Widiasarana Indonesia. Pg. 185.

The Compilation Team of the Center for Language Development, Large Dictionary of Indonesian Language, Second Edition, Jakarta: Balai Pustaka. Pg. 646.

Thomas W. Zimmerer \& Norman M. Scarborough. (2008). Entrepreneurship and Small Business Management. Jakarta: Salemba Empat. Pg. 57. (Translator: Purwoko)

Wake, Wilson. (2013). Organizational Management and Human Resources. Jakarta; Gramedia Library. Pg. 215216.

Zakiyah, Daradjat. (2009). Mental Health. Jakarta: CV. Haji Masagung. p. 16. 